\title{
JURISDICTION AND COSTS IN RECENT INTER-EU CASES OF DÉMENTI AND APOLOGY FOR FALSIFYING HISTORY
}

\author{
Piotr MOSTOWIK ${ }^{1}$, Edyta FIGURA-GÓRALCZYK ${ }^{2}$
}

This study covers two issues concerning the intra-EU proceedings in the cases of personality rights infringement. The core of the analyzed matters are the special (alternative) jurisdiction and the costs of the proceedings. These problems are interesting both from the theoretical and the practical standpoints. The discussed judgments concern the dissemination of statements that constitute a historical falsification that is usually caused by using the expression Polish concentration camps instead of Nazi-German concentration camps. The CJEU recently address the issue of the special (alternative) jurisdiction based on Art. 7(2) Brussels I Recast Regulation in such cases in the judgment from June 17,2021 , for the case C-800/19. This study analyses this judgment and the exclusion of jurisdiction based on 'center of life interests' in such cases for the 'indivisible' claims (e.g. the claim for apology). The problem of the costs is discussed from the perspective of the enforcement proceedings of foreign judgments in the intra-EU cases based on the German Supreme Court's judgment from July 19, 2018 (IX ZB 10/18). The high costs of such proceedings based on the German Code of Civil Procedure were analyzed from the perspective of the access to court rule based on Article 6 (1) ECHR and the jurisprudence of ECtHR.

international civil procedure access to court special jurisdiction international defamation personality rights enforcement of foreign judgments

1 | Professor, Faculty of Law and Administration, Jagiellonian University, Cracow, Poland; expert, Institut of Justice, Warsaw, Poland; piotr.mostowik@uj.edu.pl.

2 | Assistant Professor, Institute of Law, Cracow University of Economics, Poland, figurae@uek. krakow.pl; the part of publication created by E. Figura-Góralczyk was financed by the 'Potencjal' program, awarded to the University of Economics in Cracow. 


\section{Introduction}

The following comments cover issues related to cross-border proceedings concerning personality rights infringement. It was caused by the dissemination of statements that constitute a historical falsification that was brought about by using the expression Polish concentration camps instead of Nazi-German concentration camps ${ }^{3}$. The Polish Court of Appeal in Cracow issued a judgment ${ }^{4}$ in one of these proceedings. The enforcement of this judgment in Germany was blocked by the German Supreme Court (ger. Bundesgerichtshof, BGH) ${ }^{5}$. The matter of the enforcement of another judgment by the Court of Appeal in Cracow on March 23, 20216, remains open. Time will show whether this judgment is not enforced in Germany with the reference to the argumentation presented a few years ago by BGH. Similar cases were also judged by Polish Appeal Court in Białystok on September

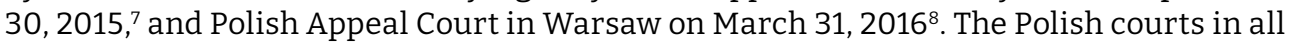
aforementioned cases decided that they have the jurisdiction to adjudicate each of them. However, Appeal Court in Warsaw had doubts about this problem, and in a similar case, this court decided to ask a preliminary question to the Court of Justice of the European Union $^{9}$. The Advocate General's opinion ${ }^{10}$ and judgment of 17 June 2021 (C 800/19) ${ }^{11}$ in the latter case have recently been issued.

As indicated in the title of this article, two matters that arise in these cases require more detailed discussion. There are no detailed comments on both aspects in the literature, yet (the literature has focused on the fundamental issue of the cross-border

3 | One of the latest examples of such situations is the article printed by Wall Street Journal about documentary "The Meaning of Hitler", see more: https://bit.ly/33fDddR (14.09.2021); see also "US daily uses 'Polish death camps' misnomer", https://bit.ly/3F6xt3f (14.09.2021).

4 | Wyrok Sądu Apelacyjnego w Krakowie z 22 grudnia 2016, I ACa 1080/16 [Court of Appeal in Cracow 22 December 2016], https://bit.ly/3ra2TkC (14.09.2021), further: 'Polish judgment of 2016', 'Polish Appeal Court in Cracow of 22nd of December 2016'. The first instance of the case was ruled by Sąd Okręgowy w Krakowie 25 kwietnia 2016 [District Court in Cracow 25 April 2016], I C 151/14, https://bit.ly/3Gcv4FP (14.09.2021).

5 | Bundesgerichtshof Beschluss IX ZB 10/18 vom 19. Juli 2018, https://bit.ly/3HK7SPi (14.09.2021), further: 'BGH judgment of 19th July 2018'.

6 | Wyrok Sądu Apelacyjnego w Krakowie z 23 marca 2021, I ACA 808/19, [Court of Appeal in Cracow 23 March 2021], https://bit.ly/3HSJoUq (14.09.2021), further: 'judgment of $23^{\text {rd }}$ March 2021', 'Polish judgment of 2021', 'Polish Appeal Court in Cracow of 23rd of March 2021'.

7 | Wyrok Sądu Apelacyjnego w Białymstoku z 30 września 2015, I ACa 403/15 [Court of Appeal in Białystok 30th September 2015], https://bit.ly/3n7Qkon (14.09.2021), further: 'Polish Appeal Court in Białystok of $30^{\text {th }}$ September 2015'.

8 I Wyrok Sądu Apelacyjnego w Warszawie z 31 marca 2016, I ACa 971/15 [Court of Appeal in Warsaw 31 March 2016], https://bit.ly/3HNH7ts (14.09.2021), further: 'Polish Appeal Court in Warsaw of 31'st March 2016'.

9 | Request for a preliminary ruling from the Sąd Apelacyjny w Warszawie (Poland) lodged on 30 October 2019 - SM v Mittelbayerischer Verlag KG, OJ C 27, 27.1.2020, p. 22-22.

10 | Opinion of Advocate General Bobek delivered on 23 February 2021, Mittelbayerischer Verlag KG v SM, Case C-800/19, ECLI: ECLI:EU:C:2021:124, https://bit.ly/33hGiKC (14.09.2021), further: 'AG Bobek opinion'.

11 I CJEU judgment from 17 June 2021 in case C-800/19, Mittelbayerischer Verlag KG v. SM, https:// bit.ly/3f4JMTe (14.09.2021), further: Case C-800/19. 
enforcement of judgments ${ }^{12}$ ). This is the problem of the court's competences and understanding of the EU law that establishes special (alternative) jurisdiction, as well as the issue of the costs of proceedings that were ultimately awarded against the plaintiff. Before discussing these matters, it is necessary-as a background and a reference point for potential future events-to recall the basic issues that arise from non-enforcement in the first court case mentioned above.

\section{Non-enforcement in Germany of foreign (Polish) judgment of $\mathbf{2 0 1 6}$ ordering denial (démenti) of the false expression}

\section{2.1. The various judicial approaches of German courts}

The question of enforcement is only the background for further analysis concerning jurisdiction. The issue of jurisdiction is not controlled by enforcement proceedings of the foreign judgment in other EU Member States according to Brussels I or I Recast Regulations. Therefore, the lack of jurisdiction cannot constitute a 'defense' against enforcement of the judgment in another EU Member State according to Brussels I or I Recast Regulations. ${ }^{13}$

In principle, judgments in the court of one Member State and enforceable in that state should be enforced in another Member State of EU.14 The foreign judgment may not be reviewed as to its substance ${ }^{15}$. In this proceeding, the special jurisdiction from Art. 5 (3) Brussels I Regulation does not affect the enforcement of the judgment in another Member State. Declaration of enforcement in another Member State is usually granted almost

12 | On details of these proceedings, see more Mostowik and Figura-Góralczyk, 2021, pp. 91-115. On details of the applied public policy clause and the reasoning by BGH, see Mostowik and FiguraGóralczyk, 2022.

13 | Article 35 para. 3 of Regulation 44/2001 of 22 December 2000 on jurisdiction and the recognition and enforcement of judgments in civil and commercial matters OJ L 12, 16.1.2001, p. 1-23, further: 'Brussels I Regulation' reads as follows: '(...) the jurisdiction of the court of the Member State of origin may not be reviewed. The test of public policy referred to in point 1 of Article 34 may not be applied to the rules relating to jurisdiction.' Similarly, Article 45 para. 3 of Regulation 1215/2012 of 12 December 2012 on jurisdiction and the recognition and enforcement of judgments in civil and commercial matters OJ L 351, 20.12.2012, p. 1-32, further: 'Brussels I Recast Regulation' reads as follows: '(...) the jurisdiction of the court of origin may not be reviewed. The test of public policy referred to in point (a) of paragraph 1 may not be applied to the rules relating to jurisdiction.'

14 | On the recognition provided for in Article 33 as the rule. See more: Wautelet, 2007, pp. 547-554. On the public order clause and refusal to recognize the foreign judgment under article 34 , see Francq, 2007, pp. 565-579.

15 | See: Mankowski, 2007, pp. 625-628; Judgment of the Court (First Chamber), 6 September 2012, Trade Agency Ltd v Seramico Investments Ltd., Case C-619/10, ECLIt identifier: ECLI:EU:C:2012:531, further: 'Trade Agency' par. 50; Judgment of the Court of 28 March 2000, Krombach v Bamberski, Case C-7/98, ECLI identifier: ECLI:EU:C:2000:164, further: 'Krombach', par. 36; Judgment of the Court (Fifth Chamber) of 11 May 2000, Renault v Maxicar, Case C-38/98, ECLI identifier: ECLI:EU:C:2000:225, further: 'Renault', par. 29; Judgment of the Court (Grand Chamber) of 28 April 2009, Apostolides v Orams, Case C-420/07, ECLI identifier: ECLI:EU:C:2009:271, further: 'Apostolides', par. 58. 
automatically under the Brussels I Regulation after the exequatur procedure ${ }^{16}$. Under Brussels I Recast Regulation, enforcement is automatic.

Polish Appeal Court in Cracow ordered the German plaintiff in its judgment on December 22, 2016, to apologize by publishing a statement that expressed regret on the use of the expression 'Polish concentration camps'17. The judgment of the Polish Appeal Court in Cracow on March 23, 2021, also ordered an apology for suggesting that Polish Home Army (pol. Armia Krajowa) was an anti-Semitic organization.

In case of the judgment by the Polish Appeal Court in Cracow on December 22, 2016, the next stages took place in Germany after filing the motion for the declaration of enforcement of foreign judgment. The German courts of lower instances approved the enforcement of this judgment. The Regional Court of Mainz (ger. Landgericht Mainz) in its judgment on January 27, 2017, and the Higher Regional Court of Koblenz (ger. Oberlandesgericht Koblenz) in its judgment on January 11, 2018, granted the enforcement clause to the judgment of the Polish Court from 2016. The Higher Regional Court of Koblenz-confirming the enforcement of the Polish judgment-stated that:

The defendant, what he does not deny himself, confirmed that he was using the phrase 'Polish extermination camps' which is an untrue fact. An incorrect statement of fact is not subject to the protection of the fundamental right under Art. 5(1.1) GG ${ }^{18}$.

The Higher Regional Court of Koblenz ruled that the enforcement of a Polish judgment in Germany would not imply a violation of freedom of speech because the term 'Polish extermination camps' is a false factual statement that is excluded from the protection provided by Art. 5(1) GG. Therefore, the ascertainment of the infringement of the plaintiff's personality rights-in the opinion of regional courts-does not violate the German public policy. However, Zweites Deutsches Fernsehen (ZDF) disagreed with those judgments. Finally, the German Supreme Court in its judgment on July 19, 2018 (IX ZB 10/18)-unlike the rulings of lower instance courts-dismissed the enforcement of the Polish judgment. Against this judgment, a claim has been recently filed in the European Court of Human Rights. ${ }^{19}$

16 | See also: Kerameus, Commentary to Article 45 of 'Brussels I' Regulation, [in:] U. Magnus, P. Mankowski (eds), Brussels I Regulation, München: Sellier, p. 667-669.

17 | By the judgment of Polish Appeal Court of December 22, 2016, the defendant - ZDF was ordered to apologize the plaintiff by publication on its Internet website for one month the following statement: 'Zweites Deutsches Fernsehen, the publisher of the Internet portal, regrets the appearance on July 15, 2013, on the www.zdf.de portal in the article (..) the expression which is the untrue and falsifying history of the Polish nation, suggesting that the death camps of Majdanek and Auschwitz were built and run by Poles, and it apologizes Karol Tendera, who was imprisoned in a German concentration camp, for violating his personality rights, in particular his national identity (sense of belonging to the Polish nation) and his national dignity'. See more: Mostowik and Figura-Góralczyk, 2021, pp. 91-115.

18 | BGH judgment of July 19, 2018, p. 7; also Bundesverfassungsgericht states that the denial of the Holocaust is not protected by freedom of thought and expression, guaranteed in Art. 5(1) of the German Constitution. Grundgesetz für die Bundesrepublik Deutschland (hereinafter referred to as 'GG'). See: BVerfG April13, 1994,1 BvR 23/94, openjur.de/u/183443.html. On German law - see more: Fahrner, 2020, pp.179-191.

19 | See the press release: https://bit.ly/3F6xFzv (14.09.2021). 
The German Supreme Court in its argumentation referred to an obvious violation of German public policy and 'freedom of opinion' (ger. Meinungsfreiheit), which is a 'constitutional right' (ger. Grundrecht). The Bundesgerichtshof states in particular that:

The enforcement of a judgment by which the convicted television broadcaster is obliged to apologize for falsification of history contained in a statement [Majdanek and Auschwitz Polish Extermination Camps] E.F.G.SP.M. existing in the opinion of the court of the sentencing State and for infringement of personality rights existing in this case in the opinion of the court of the sentencing State, clearly infringes the fundamental right to negative freedom of expression and German public policy. ${ }^{20}$

Such a decision was grounded by invoking the national public policy clause, that is, the obvious violation of German public policy by enforcement of foreign judgment. Article 34 (1) and Article 45 (1) Brussels I Regulation and 'freedom of opinion,' which is a constitutional right regulated in Art. 5 (1) GG, were proclaimed as grounds of such decision. ${ }^{21}$ The BGH stated that:

On the contrary, the subject of the legal examination in the procedure of the declaration of enforcement is rather solely the declaration for which the court of the sentencing state has sentenced the defendant. The defendant is sentenced to adopt and publish as its own the opinion that the Polish court has got from the defendant's statement. This clearly infringes the fundamental right of the defendant under Article 5(1) GG. ${ }^{22}$

According to the BGH, the defendant was obliged to accept and submit in public the statement that is an assessment (ger. Bewertung) made by the Polish court as his own, which violated the fundamental right given by Art. 5(1) GG. ${ }^{23}$

From the perspective of $\mathrm{BGH}$, the Polish judgment of 2016 violated the freedom to express an opinion as this freedom inherently involves the choice to express or not

20 | The thesis of BGH judgment in German language: 'Die Vollstreckung eines Urteils, welches der verurteilten Fernsehanstalt aufgibt, eine nach Ansicht des Gerichts des Urteilsstaats in einer Äußerung [polnischen Vernichtungslager Majdanek und Auschwitz - EFG PM] enthaltene Geschichtsverfälschung zu bedauern und sich für eine nach Ansicht des Gerichts des Urteilsstaats hierin zu sehende Persönlichkeitsrechtsverletzung zu entschuldigen, verstößt offenkundig gegen das Grundrecht auf negative Meinungsfreiheit und gegen den deutschen ordre public.' See: https:// bit.ly/3F9SKt6; https://bit.ly/3qdaL5z (14.09.2021).

21 | See more: Mostowik and Figura-Góralczyk, 2021, pp. 91-115.

22 | 'Gegenstand der rechtlichen Prüfung im Rahmen der Vollstreckbarkeitserklärung ist vielmehr ausschließlich die Erklärung, zur deren Abgabe das Gericht des Urteilsstaates die Antragsgegnerin verurteilt hat. Die Antragsgegnerin ist dazu verurteilt worden, die Bewertung, die ihre Erklärung durch das polnische Gericht erfahren hat, als eigene Meinung zu übernehmen und zu veröffentlichen. Dies verstößt offenkundig gegen das Grundrecht der Antragsgegnerin aus Art. 5 Abs. 1 GG.' (BGH judgment of July 19, 2018, p. 10).

In the following part BGH de facto reviews the substance of the case (e.g. the expression 'Polish' camps did not trigger sensation in 2013 and the defendant has not repeated such a term any more, and that the wording was detached from the entire text of the announcement and the program itself; BGH judgment of July 19, 2018, p. 11-12). See the objections (because of révision au fond) presented by Nowicka, 2019, p. 364.

23 | See more: Mostowik and Figura-Góralczyk, 2021, pp. 91-115. 
express one's opinion (ger. negative Meinungsfreiheit), that is, the right not to have one's own opinion, not pronouncing one's opinion, to silence, and not being compelled by others to express someone else's opinion as one's own. The BGH states that the impossibility of examining whether a given statement (in this case the sentence of a judgment) expresses truth or falsehood (the impossibility of falsifying a given statement) makes it an opinion (ger. Meinungsäußerung, Werturteil) ${ }^{24}$. The arguments that redirected the discourse can be considered as controversial. ${ }^{25}$ In this argumentation, a false, factual, and historical statement is categorized as an 'opinion' (ger. Meinung). The freedom of speech and opinion are bound by this category, and as this freedom is protected by Art. 5 (1) GG that caused the non-execution of the Polish judgment from 2016. From the perspective of BGH, the content of the judgment expresses the opinion (ger. Meinungsäußerung) ${ }^{26}$. The BGH states that:

The description of a-also not coherently reproduced-program announcement as a falsification of history and as a violation of the personality rights of a former concentration camp prisoner is the result of a judgmental consideration, but not a fact whose truth could be verified. ${ }^{27}$

The BGH also emphasizes that the defendant would have to join the aforementioned opinion and make it public as their own. The Bundesgerichtshof concludes that this case:

(...) concerns the question of whether the defendant can be obliged to take over a foreign opinion. If the obligation to express one's own opinion violates the negative freedom of expression under Article 5(1) GG, that is certainly the case with the obligation to publish a described assessment as one's own opinion. ${ }^{28}$

One of the possible solutions of enforcement coherent with German constitutional law would be to indicate that the apology is published due to the wordings of the judgment by the Polish court from 2016, and not the own opinion of ZDF ${ }^{29}$. However, the BGH did not refer to such a possibility.

24 | BGH judgment of July 19, 2018, p. 10-11.

25 | Argumentation presented by BGH was not focused on the claimant's relationship with the defendant but directed de facto against the sentence of court judgment. This happened by redirecting discourse from personality rights to the sentence of the Polish judgment of 2016 and applying a highly complicated and 'sublime' interpretation of the principle of freedom of opinion, raised to the rank of 'German ordre public', as a result of which BGH refused to recognize and declare the Polish judgment enforceable in the territory of Germany as 'obviously contradictory' to this order with reference to art. 34(1) Brussels I. See more: Figura-Góralczyk and Mostowik, 2022.

26 | BGH judgment of July 19, 2018, p. 11.

27|'Die Umschreibung einer - zudem nicht zusammenhängend wiedergegebenen - Programmankündigung als Geschichtsverfälschung und als Verletzung des Persönlichkeitsrechts eines ehemaligen KZ-Häftlings ist das Ergebnis einer wertenden Betrachtung, nicht jedoch eine Tatsache, deren Wahrheitsgehalt überprüft werden könnte.' (BGH judgment of July 19, 2018, p. 12).

28 |'Es geht um die Frage, ob die Antragsgegnerin zur Übernahme einer fremden Meinung verpflichtet werden kann. Wenn schon die Pflicht zur Abgabe einer eigenen Stellungnahme gegen die negative Meinungsfreiheit aus Art. 5 Abs. 1 GG verstößt, gilt dies erst recht für die Pflicht, eine vorgegebene Bewertung als eigene Meinung veröffentlichen zu müssen.' (BGH judgment of July 19, 2018, p. 13).

29 | See: Hess, 2021, p. 453. Hess suggests that it would be possible to adjust the Polish judgment. It was possible to indicate that the statement is the result of the judgment of Polish court and not the own opinion of the defendant. 
In addition to the abovementioned argumentation, the BGH argues that the declaration of enforcement by the Polish judgment of 2016 violates the constitutional principle of proportionality (ger. Verhältnismäßigkeitsgrundsatz) ${ }^{30}$. The BGH states that the obligation of the press or television to make the correction public is an infringement of their rights under Art. 5 (1) GG and Article 10 ECHR ${ }^{31}$. According to the latter, the media decides how and what they inform.

However, the BGH did not evaluate the relation between Art. 10 (2) ECHR and Art. 17 ECHR. The presented reasoning of the BGH de facto paid little attention to the important problem of the scope and 'borders,' which were given by the international legislator to the notion of 'freedom of speech,' 'freedom of opinion,' and 'freedom of expression,' under Article 10 ECHR, and its relation to Art. 17 ECHR. In the jurisprudence of ECHR in cases of Holocaust denial, the application of discussed Art. 10 ECHR is excluded by Art. 17 ECHR (prohibition of abuse of rights) ${ }^{32} \cdot{ }^{33}$ Under Art. 17, nothing in ECHR may be interpreted as implying to engage in any activity or perform any act aimed at the destruction of any of the rights and freedoms, as well as their limitation, to a greater extent than it is provided for in the Convention. Additionally, the wording of Art. 10 ECHR stresses that freedom of expression is considerably important but remains a limited and conditional right. Particularly, freedom of the press is of cardinal importance in a democratic society, but it is not unlimited. Art. 10 (2) ECHR imposes an obligation that consists of the duty to practice reliable journalism ${ }^{34}$. The resulting principle from those provisions is that the media should not use the opportunity to declare the false statements as legal. Publishing some expressions or statements may render the person, who is concerned civilly liable or even criminally punishable, in cases of defamation or insulting language. ${ }^{35}$

\section{| 2.2. Judgement of 2021 in a partly comparable case}

The same observations apply to the possible enforcement of the judgment of March 23,2021 . Also, in this proceeding the special jurisdiction of the Polish court based on Art. 7 (2) Brussels I Recast Regulation does not affect the enforcement of this judgment in Germany. In this recent judgment of March 23, 2021, the same defendant-ZDF and additionally UFA Fiction (both the producers of the TV series)-have been obliged by the Court of Appeal in Cracow to apologize to the World Union of Home Army Soldiers (pol. Armia Krajowa) for infringement of personality rights. The infringement took place in the aforementioned series, where the Polish partisan unit, which was a part of the Home Army

30 | BGH judgment of July19, 2018, p. 13.

31 | Convention for the Protection of Human Rights and Fundamental Freedoms, opened for signature in Rome on November 4,1950, www.echr.coe.int/pages/home.aspx?p=basictexts, further as 'ECHR'.

32 I See: Lobba, 2015, pp. 240-241; Kamiński (2020, p. 83) observes that Art. 17 of ECHR (according to which certain expressions are deprived of the protection stemming from Art. 10) seems to be reserved for the statement which must be deemed as going contrary to "the underlying values of the Convention". In our opinion such a situation occurs when concentration and death camps during War II are called "Polish" ones.

33 | See more: Figura-Góralczyk and Mostowik, 2022.

34 | See more: Garlicki, 2010, pp. 599 et seq.; Garlicki, 2010, pp. 12 et seq.; Schabas, 2015, pp. 468 et seq. 35 | ECtHR, March 29, 2001, Thoma v. Luxembourg, Reports 2001-III. See: Introduction to the European Convention on Human Rights The rights guaranteed and the protection mechanism, Council of Europe, 2005, p. 22-27, https://www.echr.coe.int/LibraryDocs/DG2/HRFILES/DG2-ENHRFILES-01 (2005).pdf (14.09.2021). 
(Armia Krajowa), is suggested to be an anti-Semitic group ${ }^{36}$. The apology should have been broadcast on Polish public television channels and in three German television channels, where the series was shown and presented on the internet websites of the defendants. Similar to the abovementioned judgment of 2016, this Polish judgment of 2021 was based on the infringement of personality rights and includes the duty to officially apologize for this infringement. However, in case of the judgment of 2021, Home Army was personally mentioned in the examined movie. Contrarily, in the judgment of 2016, Karol Tendera was not defamed in person. This circumstance is important from the perspective of the applicable civil law (the rules of protection of personality rights), and from the grounds of jurisdiction and interpretation of Art. 7 (2) Brussels I Recast Regulations, as discussed below.

Additionally, the proceeding concerning enforcement of the judgment of 2021 is subject to Brussels I Recast Regulation as the proceeding started in 2016. Based on Art. 39 of this Regulation, the Polish judgment of 2021 is subject to automatic enforcement in Germany, that is, without exequatur procedure. However, based on Art. 46 and 45 (1) (a) Brussels I Recast Regulation, the enforcement of the judgment may be on the application of the person against whom enforcement is sought refused in case the judgment is contrary to public policy. The near future will show the fate of the Polish judgment of 2021, in particular its enforcement in Germany

\section{Issue of jurisdiction}

\section{| 3.1. International civil procedure aspects in the disputes}

The jurisdiction of Polish courts in cases concerning violation of personality rights committed by means of a foreign online publication, which mentioned the expression 'Polish concentration camps,' was confirmed in several judgments (Polish Appeal Court in Białystok of September 30, 2015; Polish Appeal Court in Warsaw of March 31, 2016; Polish Appeal Court in Cracow of December 22, 2016). Similarly, the jurisdiction of Polish courts was confirmed in the case of judgment by the Polish Appeal Court in Cracow on March 23, 2021. However, this matter was not so obvious for Appeal Court in Warsaw that decided to ask a preliminary question to the CJEU in case C-800/1937.

36 | The court stated that 'obliges each of the defendants to submit an apology within seven days of the judgment becoming final, between 8.00 p.m. and 8.30 p.m., in white text on a black background that is at least the same size then opening credits of the series (...) with a visible-bold title (...) and the following content: 'Producers of the film 'Our Mothers Our Fathers' i.e. Tv ZDF and the company UFA Fiction, as a result of losing a court trial, apologize World Union of Home Army Soldiers with the seat in Warsaw, for violating his personal rights by identifying the Polish partisan unit in the above-mentioned film as having detachment with (...) which gives rise to an unauthorized suggestion that this Polish military organization was anti-Semitic in nature'. See more: https://bit. ly/3zILzXz; https://bit.ly/3rolkbm; https://bit.ly/3fagDGa (14.09.2021).

37 | For first comments see post from June 17, 2021, of T. Lutzi, Case C-800/19: CJEU Limits Scope of 'Center of Interests' Jurisdiction for Online Infringements of Personality Rights (https://bit. ly/3qbugeF); from June 18, 2021, of G. van Calster, Mittelbayerischer Verlag: the CJEU surprisingly reigns in Article 7(2) centre of interests jurisdiction in cases of online defamation, https://gavclaw. com/tag/c-800-19/; from June 29, 2021, of E. Figura-Góralczyk, CJEU Rules on Jurisdiction in Violation of Personality Rights Claim, C-800/19, https://bit.ly/3qat9vF (14.09.2021). 
In this case, the plaintiff (SM) is a Polish national, who lives in Poland, and a former prisoner of Auschwitz extermination camp during World War II. He based the lawsuit on the infringement of his personality rights based on the online article that was published by Mittelbayerischer Verlag KG (the local publisher), having the title: "Ein Kämpfer und sein zweites Leben" (The Fighter and his Second Life) in Germany, on the website that was accessible in Poland. This article presented in the German language the pre- and post-war life of Israel Offman, a Jewish person who survived the Holocaust. This online article had the statement that Israel Offman's sister 'was murdered in the Polish extermination camp of Treblinka' ${ }^{38}$. SM belongs to group of former prisoners of Nazi-German extermination camps. SM claims that the words 'Polish extermination camp Treblinka' that were used in the online article, instead of 'Nazi-German extermination camp,' infringed the national identity and dignity of SM, which according to Polish material law (Art. 23 and 24 of Polish Civil Code) causes infringement of personality rights.

These case facts led to the Appeal Court in Warsaw raising two questions which could be summed up in the following way: do Polish courts have jurisdiction in such cases based on Article 7 (2) Brussels I Recast Regulation? The CJEU answered the question in the following way: Article 7(2) Brussels I Recast Regulation

\footnotetext{
(...) must be interpreted as meaning that the courts of the place in which the center of interests of a person claiming that his or her personality rights have been infringed by content published online on a website is situated have jurisdiction to hear, in respect of the entirety of the alleged damage, an action for damages brought by that person only if that content contains objective and verifiable elements which make it possible to identify, directly or indirectly, that person as an individual ${ }^{39}$.
}

\section{| 3.2. Recent jurisprudence of Court of Justice of European Union}

The analyzed case concerns the jurisdiction of the court of the Member State based on 'center of life interests' of the person, whose personality rights were infringed by the online publication (Article 7(2) of the Brussels I Recast Regulation) ${ }^{40}$. The CJEU introduced this broad interpretation of Art. 7(2) of Brussels I Recast Regulation in case eDate ${ }^{41}$ by creating the jurisdiction ground based on 'center of life interests' of the victim. This jurisdiction ground allows the court to judge all claims arising from the violation of personality right ${ }^{42}$. Therefore, the broad interpretation of 'center of life interests' was confirmed by the CJEU in case C-194/16 (Bolagsupplysningen) ${ }^{43}$. However, the specificity of case C-800/19 is that the plaintiff (SM) is not personally addressed (name or surname) in the online article. Contrarily, in this case the plaintiff belongs to the group addressed

38 | AG Bobek opinion, para 13. In original language version of the article the expression was the following: 'im polnischen Vernichtungslager Treblinka ermordet worden war'.

39 | Case C-800/19, para 47.

40 | See: https://bit.ly/3F6zEDX (14.09.2021).

41 Judgment of the Court (Grand Chamber) of October 25, 2011, - eDate Advertising GmbH v X (C-509/09) and Olivier Martinez and Robert Martinez v MGN Limited (C-161/10), Joined Cases C-509/09 and C-161/10, European Court Reports 2011 p. I-10269, https://bit.ly/3JZqKf9, further: 'case eDate'.

42 | See more: Bogdan, 2011, pp. 483-491; Reymond, 2011, pp. 493-506.

43 Judgement of the Court (Grand Chamber) of 17 October 2017 - Bolagsupplysningen OÜ, Ingrid Ilsjan v. Svensk Handel AB, Case C-194/16, ECLI:EU:C:2017:766, https://bit.ly/3q6UO0x (14.09.2021). 
in the article (the group of prisoners of Nazi-German extermination camps). SM has their center of life interests in Poland. SM has a habitual residence in Poland and is a Polish national. Therefore, SM filed the lawsuit with claims that are 'indivisible' (e.g. the claim for publishing an apology to the plaintiff for the false statement). To judge such claims, the Polish court should have the jurisdiction based on the 'center of life interests' according to Article 7 (2) Brussels I Recast Regulation in the meaning introduced by the eDate case.

According to AG Bobek ${ }^{44}$, the jurisdiction of the courts in such cases based on the 'center of life interests' does not require that the allegedly harmful online content names a particular person. However, there should be a close connection between that court and the action at issue, and thereby, ensuring the sound administration of justice. Contrarily, the Commission argued, in essence, that a person whose personality rights, according to its claim, would be infringed, should be able to bring an action before the court that has jurisdiction in the center of life interests, if this person was mentioned by name in the online publication in question.

Moreover, AG Bobek has proposed, based on AG Cruz Villalón in eDate opinion ${ }^{45}$, the proportionality test that should clarify the jurisdiction in online infringements of personality rights.

The 'centre of gravity' test [proposed by AG Bobek should] to be composed of two cumulative elements, one focusing on the claimant and the other on the nature of the information at issue. The courts of a Member State would have jurisdiction only if that were the place of the claimant's centre of interests and if 'the information at issue [was] expressed in such a way that it may reasonably be predicted that that information is objectively relevant in [that Member State ${ }^{46}$.

As a result of this test AG Bobek arrives at the following assessment:

...indeed [it is] difficult to suggest that it would have been wholly unforeseeable to a publisher in Germany, posting online the phrase 'the Polish extermination camp of Treblinka', that somebody in Poland could take issues with such a statement. It was thus perhaps not inconceivable that 'the place where the damage occurred' as a result of that statement could be located within that territory, especially in view of the fact that that statement was published in a language that is widely understood beyond its national territory. Within that logic, while it is ultimately for the national court to examine all those matters, it is difficult to see how jurisdiction under Article 7(2) of Regulation No 1215/2012 could be axiomatically excluded. ${ }^{47}$

Consequently, the center of gravity test proposed by AG Bobek allows the jurisdiction in cases concerning 'Polish extermination camps' (also for the 'indivisible' claims, e.g. the claim for apology arising from the online violation of personality right) based on 'center of life interests' from Article 7 (2) of Brussels I Recast Regulation.

44 | See: https://bit.ly/3t9HjPx (14.09.2021).

45 | Opinion of Advocate General Cruz Villalón delivered on 29 March 2011, ECLI:EU:C:2011:192, https://bit.ly/3JPVRKh (14.09.2021).

46 | AG Bobek opinion, para 64. See in detail the centre of gravity test in AG Bobek opinion, paras 65-73.

47 | AG Bobek opinion, para. 74. 
However, the CJEU in the discussed judgment arrives at the different conclusion. The CJEU de facto excludes the jurisdiction of Polish courts in such cases of 'indivisible' claims. CJEU did not follow the proposed center of gravity test proposed by AG Bobek. The Court stated that the sound administration of justice requires such interpretation of basis of jurisdiction in Article 7(2) Brussels I Recast Regulation and that the center of life interests is located in the country foreseeable for the defendant. This requires the clarification of the previous judgments by CJEU (e.g. eDate case). The CJEU introduced this in such a way that the connection between the plaintiff and alleged online material should be based on objective and verifiable elements that allow the person to be identified, directly or indirectly, and individually. The CJEU stated in the analyzed case that SM (plaintiff) was clearly neither directly nor indirectly identified individually in the content published on the Mittelbayerischer Verlag website. The plaintiff bases the claim of an infringement of their personality rights on the fact that SM belongs to the Polish nation and was the prisoner of an extermination camp. The CJEU states that in such a situation, there is no particularly close connection between the court, in the area of jurisdiction, the center of the life interests of the person claiming the personality rights infringement lies, and the dispute in question ${ }^{48}$. Therefore, the Polish courts do not have jurisdiction to hear all 'indivisible' claims based on Article 7(2) Brussels I Recast Regulation.

In this way, the CJEU limited the interpretation of 'center of life interests' in Article 7(2) of the Brussels I Recast Regulation. To achieve this aim, the CJEU stated that the online content should contain objective and possible elements to be verified, allowing for the direct or indirect individual identification of the person infringed. However, the CJEU did not limit the possibility to sue based on the jurisdiction from Article 7(2) Brussels I Recast Regulation in case of claims that may be 'divided' between the territories of the counties (mosaic principle) -for example, the compensation claim.

This judgment seems to be 'the nod to the side' of legal certainty and predictability in cases concerning jurisdiction for online personality rights infringement. The new criteria introduced by the CJEU was forced by the specificity of this case, where the plaintiff was not directly or indirectly mentioned in the alleged online article, which is typical in cases concerning defamation by the expression Polish concentration camps.' However, the opinion of AG Bobek seems to propose a better solution (center of gravity test) to enhance legal certainty and predictability in such cases than the judgment of CJEU ${ }^{49}$.

At the end of these remarks, it is worth adding that such or another interpretation of the quoted European Union's provisions on jurisdiction, as well as the last interpretation of CJEU given in judgment of 17 June 2021 (case C-800/19), is not the argument for nonenforcement of foreign judgment because of the another interpretation of Article 7 para. 2 of Brussels I Recast Regulation. In particular it does not mean that there is no obligation to enforce in Germany the judgment given in civil matter in another Member State (e.g. Polish judgements of 2016 and 2021). Under Article 45 (3) of Brussels I Recast Regulation the jurisdiction of the court of origin may not be reviewed in the state of enforcement.

48 | Case C-800/19, para 45.

49 | See more the post of Lutzi (17 June 2021); Case C-800/19: CJEU Limits Scope of 'Centre of Interests' Jurisdiction for Online Infringements of Personality Rights. Available at: https://bit.ly/3fau0X3 (14.09.2021). 
Moreover, the test of public policy may not be applied in the last one to the rules relating to jurisdiction. ${ }^{50}$

\section{The reimbursement of costs of proceedings}

\subsection{The particular circumstances of the cases}

The cost of the trial is not regulated in EU law, in particular, neither Brussels I, nor I Recast Regulations have provisions concerning this matter. This matter is regulated in the national laws of EU Member States. In Germany, the costs of the trial in civil cases are regulated by the provisions of title $5 \S$ 91-107 of the German Code of Civil Procedure (ger. Zivilprozessordnung, ZPO). Based on $\S 91 \mathrm{ZPO}$ as a rule, the costs of the trial are borne by the losing party. The BGH in its judgment on July 19, 2018, unlike the rulings of German courts of lower instances, dismissed the enforcement of the Polish judgment of 2016 and ordered the plaintiff (applicant) to pay the amount of $€ 4000$ as the cost of exequatur proceedings held in Germany.

The costs were set in Polish currency at circa 18500 PLN.'51 In practice, it is a large sum for the Polish pensioner, as it is 8 times more than the average pension and 16 times more than the amount of the most frequently received pension at that time. Furthermore, this ruling also raises a theoretical issue. It seems, that the problem of high costs of the enforcement proceeding may raise concerns from the perspective of the right to a fair trial (Art. 6 ECHR) 52 .

\section{4.2. Standards of Council of Europe (jurisprudence of European Court of Human Rights)}

There are several important principles derived from the decisions of the European Court of Human Rights that should be mentioned. As the matter of the costs of the trial is regulated in the national laws of the Member States, and not in Brussels I or I Recast Regulations, the problem of mutual application of the ECHR and EU law is not relevant for this analysis ${ }^{53}$. In this case law of ECtHR, the requirement to pay the fees and expenses is not-in principle-evaluated as a restriction of the right to a fair trial. However, the ECtHR

50 | The exceptions (policyholder, the insured, a beneficiary of the insurance contract, the injured party, the consumer or the employee as the defendants, as well as exclusive jurisdiction) are not relevant to the discussed cases.

51 In German: 'Der Antrag des Antragstellers, das Urteil des Appellationsgerichts Krakau, Polen, vom 22. Dezember 2016 - IACa 1080/16 - mit der Vollstreckungsklausel zu versehen, wird abgewiesen. Der Antragsteller trägt die Kosten des Verfahrens. Der Wert des Verfahrens wird auf $4.000 €$ festgesetzt.' https://bit.ly/3Gepvqn (14.09.2021).

52 | Unacceptably high court costs were raised by Netherlands' courts while applying public order clause Middelburg, 23 September 2009, Nr. 63417/HA ZA 08-306, See, B. Hess, T. Pfeiffer, Interpretation of the Public Policy. Exception as referred to in EU Instruments of Private International and Procedural Law, Commissioned by the European Parliament, Brussels 2011, PE 453.189, p. 55; B.Hess., Europäisches 2021, p. 451. See also: Hofmański and Wróbel, 2010, pp. 294-300.

53 | See about the relation of EU law and European Charter on Human Rights: Kargopoulos, 2015, pp. 96-100; Opinion 2/13 Draft Agreement on Accession of the European Union to the ECHR, para 170. 
points out that the established 'financial barriers' must consider the balance (reasonable proportionality relationship) between the interest of the state in collecting court fees and the interest of the party in pursuing claims, and (defending individual rights) in court proceedings.

ECHR secures to everyone the right to have any claim relating to their civil rights and obligations brought before a court or tribunal. In this way, that provision embodies the 'right to a court.' One aspect of this right is the 'right of access' that is the right to institute proceedings before a court in civil matters. However, it is an aspect that makes it possible to benefit from the further guarantees laid down in paragraph 1 of Article $6 .{ }^{54}$

The ECtHR has indicated that such limitations must pursue a legitimate aim, and there must be a reasonable relationship of proportionality between the means employed and the legitimate aim sought to be achieved. ${ }^{5556}$ In the decision of ECtHR of April 27, 2000, Tiemann versus France and Germany, ${ }^{57}$ it was reiterated that it is not the ECtHR's task to substitute its own assessment of the facts and evidence for that of the national courts. Its task is to establish whether the evidence was presented such that it guarantees a fair trial. In addition, Article 6 (1) of the ECHR does not lay down any rules on the admissibility or probative value of evidence or on the burden of proof, which are essentially a matter for domestic law.

An important reasoning has been recently presented by the ECHR inter alia in its judgment of July 26, 2005, Podbielski and PPU Polpure v. Poland ${ }^{58}$ :

In the present case the applicant had to desist from pursuing his case before civil courts because his company was unable to pay the court fee (...); which it had been required to pay for proceeding with the appeal. It is true that no right to appeal in civil cases can be inferred from the Convention and that, given the nature of appeal proceedings and the fact that a person has already had his case heard before the first-instance court, the State would in principle be allowed to put even strict limitations on access to a court of appeal. It is also true that in the Tolstoy-Miloslavsky v. the United Kingdom case, the Court found that the requirement to secure a significant sum for the anticipated legal costs of the applicant's opponent in appellate proceedings had pursued a 'legitimate aim', especially given the poor prospects of success in the applicant's appeal. It also attached 'great weight' to the fact that the case had been heard for 40 days at first instance and, in that context, stressed that in cases where access to a court was concerned, the entirety of the proceedings had to be taken into account (para. 61-67 of this

54 | See: Golder v. the United Kingdom, judgment of 21 January 1975, Series A no. 18, p. 16-18, §§ 34 in fine and 35-36, and Kreuz v. Poland, no. 28249/95, §§ 52 et seq., ECHR 2001 VI.

55 | See the case: Brualla Gómez de la Torre v. Spain, judgment of 19 December 1997, Reports of Judgments and Decisions 1997-VIII, p. 2955, § 33, and Tolstoy Miloslavsky v. the United Kingdom, judgment of 13 July 1995, Series A no. 316-B, p. 80-81, §§ 61 et seq.

$56 \mid$ The court added (point 48), that "the requirement to pay fees to civil courts in connection with claims or appeals cannot be regarded as a restriction on the right of access to a court that is incompatible per se with Article $6 \S 1$ of the Convention. However, the amount of the fees assessed in the light of the particular circumstances of a given case, including the applicant's ability to pay them, and the phase of the proceedings at which that restriction has been imposed, are factors which are material in determining whether or not a person enjoyed that right of access and had "a ... hearing by [a] tribunal” (see Kreuz v. Poland, no. 28249/95, §§ 52 et seq., ECHR 2001 VI, Tolstoy Miloslavsky v. the United Kingdom, judgment of 13 July 1995, Series A no. 316-B, pp. 80-81, §§ 61 et seq.).'

57 | Application no. 47457/99, 47458/99, https://bit.ly/3najx26 (14.09.2021).

58 | Application no. 39199/98; https://bit.ly/3HJY2gq (14.09.2021). 
case). However, restrictions which are of a purely financial nature and which, as in the present case, are completely unrelated to the merits of an appeal or its prospects of success, should be subject to a particularly rigorous scrutiny from the point of view of the interests of justice. ${ }^{59}$

The arguments presented in the ECHR judgment of May 24, 2006, Weissman and Others v. Romania, ${ }^{60}$ are also worth recalling. Notwithstanding the margin of appreciation enjoyed by the State in this area, the Court emphasizes that a restriction on access to a court is only compatible with Article $6 \S 1$, if it pursues a legitimate aim, and if there is a reasonable degree of proportionality between the means used and the aim pursued. In particular, bearing in mind the principle that the Convention is intended to guarantee not rights that are theoretical or illusory, but rights that are practical and effective. The Court reiterates that the amount of the fees, assessed in consideration of the particular circumstances of a given case, including the applicant's ability to pay them and the phase of the proceedings at which that restriction has been imposed, are factors that are material in determining whether or not a person enjoyed their right of access to a court or whether, on account of the amount of fees payable, the very essence of the right of access to a court has been impaired. ${ }^{61}$

\section{Final remarks}

The issue of the court's competency and understanding of the EU law that establishes special (alternative) jurisdiction, and the problem of the costs of proceedings in cases concerning online violation of personality rights are interesting issues discussed in the recent jurisprudence. They are peripheral matters of the problem of non-enforcement of Polish judgment of 2016 in Germany because of the BGH judgment of July 19, 2018, particularly, combined with the ECJ judgment of 2021.

Under EU rules of 'judicial co-operation in civil and commercial matters,' every Member State can refuse to recognize or enforce a foreign judgment because of the fundamental principles of local public policy ${ }^{62}$. Such a possibility is necessary because the legal system in which such an institution would not be provided for, would be like 'a vehicle without brakes.' ${ }^{63}$ The need for the existence of such an exceptional clause, even

59 | It should be pointed additionally the following fragment out: "66. The Court notes that, indeed, the courts at several instances heard Mr Podbielski's case and that, eventually, the fee for lodging his company's appeal of 29 November 1996 was significantly reduced (...). Yet, in contrast to the Tolstoy-Miloslavsky case, the money that the applicant was obliged to secure did not serve the interests of protecting the other party against irrecoverable legal costs. Nor did it constitute a financial barrier protecting the system of justice against an unmeritorious appeal by the applicant. Indeed, the principal aim seems to have been the State's interest in deriving income from court fees in civil cases."

60 | Application no. 63945/00; https://bit.ly/3r1pRdq (14.09.2021).

61 | See more: Guide on Article 6 of the European Convention on Human Rights, Strasbourg 2020, https://bit.ly/3tbceuV, pp. 22-33 (14.09.2021).

62 | See more: Francq, 2007, p. 568. See also: Frąckowiak-Adamska, 2015, pp. 191-218. Additional arguments are presented by Nowicka, 2019, pp. 329 et seq.

63 | See: Siehr, 2008, p. 223; Sonnenberger, 2006, pp. 29-53. 
for intra-EU relations of one international organization, is justified by large differences in legal systems and the necessity to safeguard against the adverse consequences of future foreign law, specifically in a form that cannot be predicted at present. However, it is not easy to agree with the judgment of $\mathrm{BGH}$, which twice recognizes the content of the given judgment of the Polish Court of 2016 for the 'opinion'. The notion of opinion, adopted twice by the BGH in the sentence and developed in further reasoning, may mean that any correction ordered by a foreign court would not be enforced in future practice (published widely, e.g. in the press or television). The general excuse for this judgment is that such information (resulting from the sentence) is not falsifiable, and consequently, it would violate the 'negative aspect of freedom of speech.' In practice, this would mean a far-reaching limitation of the effectiveness of EU judicial cooperation in civil matters, especially in cases involving the infringement of personality rights ${ }^{64}$.

In our opinion, standards of the European Convention on Human Rights should be taken into deep consideration. Therefore, the discussed BGH judgment of 2018 can be, from our point of view, evaluated as questionable. A tool, such as the order public clause, is necessary even under automatic enforcement of the Brussels I Recast Regulation. However, the introduction of standards and limits of EU ${ }^{65}$ and international law to the application of national public order is to be welcomed. In particular, in the discussed cases that are not only of private law character the public law standards of mass media and journalism should be taken into account.

As far as the issue of cost reimbursement is concerned, in the given particular case, the controversy may arise over the scope of cost reimbursement given the ECHR principle of fair access to court and its practical aspects. An opinion may be presented that awarding such costs by the BGH for the 'theoretically winning' case (following the principles of EU law) and-in this inter-state configuration and the life situation of the retiree-is questionable. It is standard in civil proceedings that internal law provides, in exceptional circumstances, to waive the award of costs or reduce them. Furthermore, even from a non-judicial perspective, one might wonder if the ZDF should have demanded them, but that is beyond the scope of this study. Such an approach by the BGH may additionally cause fear of the enforcement of judgments from other EU countries in Germany in the future, and thus deprive the EU law (regarding judicial cooperation in civil matters) of its practical effectiveness.

Before referring to the problem of jurisdiction, one must recall that the jurisdiction grounds adopted in the issuing state, in the discussed cases, are not controlled in enforcement proceedings of other EU Member States. In other words, the lack of jurisdiction cannot constitute a 'defense' against enforcement of the judgment in another EU Member State according to Brussels I or I Recast Regulations ${ }^{66}$. The CJEU in the case C-800/19, strengthened the legal certainty and predictability in cases concerning jurisdiction for online infringement of personality rights based on Art. 7 (2) Brussels I Recast Regulation. The new criteria introduced by the CJEU was forced by the specificity of the case C-800/19, where the plaintiff was neither directly nor indirectly mentioned in the alleged online article. Such a situation is typical in cases concerning defamation because of use the expression 'Polish concentration camps.' In this way, the CJEU excluded the jurisdiction

64 | See more Figura-Góralczyk and Mostowik, 2022.

65 | EU public order is discussed by Basedow, 2004, pp. 291 et seq.

66 | Article 45, para. 3 of Brussels I Recast Regulation. 
of Polish courts based on 'center of life interests' in such cases of 'indivisible' claims (e.g. the claim for apology). However, the CJEU did not limit the possibility to sue based on the jurisdiction from Art. 7 (2) Brussels I Recast Regulation in case of claims that may be 'divided' between the territories of the counties (mosaic principle)-for example, the compensation claim. The opinion of AG Bobek, in this case, seems to propose a better solution (center of gravity test) to enhance legal certainty and predictability than the judgment of CJEU.However, this new interpretation of Art. 7 (2) of the Brussels I Recast Regulation presented by CJEU in 2021 does not mean a change to the general rule saying that a judgment issued in EU state should be enforced in another Member State. According to Art. 45 (3) of Brussels I Recast Regulation, the court of the state of enforcement cannot at this moment question the jurisdiction of the state where the judgment was given in civil matter. 


\section{Bibliography}

Basedow J. (2004) 'Die Verselbständigung des europäischen ordre public' in Coester, M., Martiny, D., Prinz von Sachsen Gessaphe, K.A (eds.) Privatrecht in Europa. Vielfalt, Kollision, Kooperation, Festschrift fur Hans Jürgen Sonnenberger zum 70. Geburtstag, München: Verlag C.H. Beck.

Bogdan M. (2011) 'Defamation on the Internet, Forum Delicti and the E-Commerce Directive: Some Comments on the ECJ Judgment in the eDate Case', Yearbook of Private International Law, Vol. 13, pp. 483-491.

Fahrner M. (2020) 'Back to the Roots - the Obligation(s) to Punish Negationism in German' in P. Grzebyk (ed.). Responsibility for negation of international crimes. Warsaw: Wydawnictwo Instytutu Wymiaru Sprawiedliwości.

Frąckowiak-Adamska A. (2015) 'Time for a European 'full faith and credit clause', Common Market Law Review, 52(1), pp. 191-218.

Francq S. (2007) in Magnus U., Mankowski, P. (eds), Brussels I Regulation. München: Sellier.

Garlicki L. (2010a) in L. Garlicki (ed) Konwencja o Ochronie Praw Człowieka i Podstawowych Wolności. Komentarz do artykułów1-18, t.1. Warszawa: Wydawnictwo C.H. Beck.

Garlicki L. (2010b) Wolność wypowiedzi dziennikarza - przywilejei odpowiedzialność, EPS, 2010/1, pp. 12-17.

| Hess B. (2021) Europäisches Zivilprozessrecht. Berlin-Boston: Walter de Gruyter GmbH.

Hess B., Pfeiffer T. (2011) 'Interpretation of the Public Policy. Exception as referred to in EU Instruments of Private International and Procedural Law' Commissioned by the European Parliament, Brussels.

Hofmański P., Wróbel A. (2010) in L. Garlicki (ed.) Konwencja o ochronie praw człowieka i podstawowych wolności. Komentarz do artykułów 1-18, t. I. Warszawa: Wydawnictwo C.H. Beck.

Kamiński I. C. (2020) 'Debates over History and the European Convention on Human Rights' in Grzebyk, P. (ed.) Responsibility for negation of international crimes. Warsaw: Wydawnictwo Instytutu Wymiaru Sprawiedliwości.

Kargopoulos A.-I. (2015) 'ECHR and the CJEU Competing, overlapping, or Supplementary Competences?', The European Criminal Law Associations' Forum, 2015/3, pp. 96-100.

Kerameus K. (2007) 'Commentary to Article 45 of 'Brussels I' Regulation' in Magnus, U., Mankowski, P. (eds) Brussels I Regulation, München: Sellier.

Lobba P. (2015) 'Holocaust Denial before the European Court of Human Rights: Evolution of an Exceptional Regime', European Journal of International Law, 26(1), pp. 237-253. 
Mostowik P., Figura-Góralczyk E. (2021) 'Polish Death Camps' as an 'Opinion' of which Expressing is Protected by German Law? Questionable Bundesgerichtshof's Judgement of 19.7.2018' in Bainczyk, M., Kubiak-Cyrul, A. (eds.) States' responsibility for international crimes: Reflections upon the Rosenburg exhibition. Stuttgart: Franz Steiner Verlag.

Mostowik P., Figura-Góralczyk E. (2022) 'The issue of limits to national order public in non-enforcement of judgements in EU: Case study', Journal of Private International Law, in print.

Nowicka A. (2019) 'Wykonywanie orzeczeń sądów polskich w sprawach cywilnych w państwach członkowskich Unii Europejskiej, z uwzględnieniem ewentualności powołania się przez sądy zagraniczne na klauzulę porządku publicznego' in A. Radwan, M. Berent (eds.) Prawda historyczna a odpowiedzialność prawna za jej negowanie lub zniekształcanie. Warszawa: Wydawnictwo C.H. Beck.

Reymond M. (2011) 'The ECJ eDate Decision: A Case Comment', Yearbook of Private International Law, Vol. 13, pp. 493-506.

Schabas W. A. (2015) The European Convention on Human Rights: A Commentary. Oxford: Oxford University Press.

Siehr K. (2008) ‘Kollisionen des Kollisionsrechts' in Baetge D., Hein J. v., Hinden M. v. (eds), Die richtige Ordnung. Festschrift fürJan Kropholler zum 70. Geburtstag, Tübingen: Mohr Siebeck.

Sonnenberger H.J. (2006) 'Wandlungen und Perspektiven des familienrechtlichen ordre public' in Freitag R., Leible S., Sippel H., Wanitzek U. (eds), Internationales Familienrecht für das 21. Jahrhundert. Symposium zum 65. Geburtstag von Professor Dr. Ulrich Spellenberg, München: Sellier.

Wautelet P. (2007) in Magnus U., Mankowski P. (eds), Brussels I Regulation, München: Sellier. 